\title{
Role of Payment for Environmental Services in Improving Livelihoods and Promoting Green Economy: Empirical Evidence from a Himalayan Watershed in Nepal
}

\author{
K. P. Pant ${ }^{1, \#}$ and G. Rasul ${ }^{2}$ \\ ${ }^{1}$ College of Arts, Kathmandu University \\ Hattiban, Lalitpur, Nepal \\ ${ }^{2}$ International Centre for Integrated Mountain Development \\ Lalitpur, Nepal

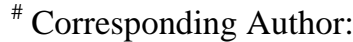

Tele: (977) 1 4881005; Fax: (977) 1 524227; E-mail: Krishna.Pant@ku.edu.np

\begin{abstract}
Although mountains are rich in natural resources and provide vital ecosystem services to the global community, mountain people are marginalised. As the ecosystem services they provide are mostly free of charge, they have no incentive to invest in the conservation. We examine the feasibility of improving their livelihoods through the sale of water services to downstream communities. Using hydrometeorological data, we assessed the effects of forest conservation on water yield and estimated the value of water services to downstream communities. Results show that if a system of payment for ecosystem services is established, mountain communities can improve their livelihoods by converting their farmland into conservation areas. However, it will take 15 years to increase the water yield, which means that external assistance is required in early years. Policy measures are suggested to establish a market for ecosystem services to encourage upstream communities to take conservation measures.
\end{abstract}

KEYWORDS: Forest conservation, Payments for ecosystem services, Water supply, Livelihood improvement, Green economy

\section{Introduction}

The concept of a green economy has been gaining currency recently as a way of linking economic growth and environmental sustainability. The green economy, as defined by the United Nations Environment Programme (UNEP, 2010) is an economic system "that results in improved human well-being and social equity, while significantly reducing environmental risks and ecological scarcities". It highlights the value of nature for economic growth and human wellbeing and focuses on investment in the Earth's natural capital, such as land, soil, forests, biodiversity, water, watersheds, and other natural resources, for ecological 
resilience and economic efficiency to reduce poverty and enhance sustainability. It advocates for policies that promote investment in environmentally significant sectors, while contributing to the pursuit of sustainable development and poverty eradication.

Although mountains are rich in natural resources and provide vital ecosystem services to the global community, mountain people are economically marginalised. Poverty and vulnerability are relatively high in the mountain regions of developing countries (Hunzai et al., 2010). For mountain regions, particularly those with developing economies - where millions of people live in a fragile environment and depend mainly on the natural environment for their livelihoods and wellbeing - the usefulness and acceptance of the green economy approach is largely dependent on its ability to balance the conservation of natural capital with poverty reduction and human wellbeing. Mountain people will not adopt this approach, no matter how environmental sound, unless it generates economic benefits to them. In promoting the green economy, the major challenge is, therefore, to generate economic activities that improves livelihoods and preserve and enhance environmental quality by using natural resources more efficiently.

The demand for mountain ecosystem services is increasing steadily as a result of population growth, climate change, globalisation, increasing urbanisation, and industrialisation. Demand for hydrological services has increased tremendously in Nepal, particularly in urban areas. Shortage of fresh water is a growing problem in many parts of the world. More than one billion people in the developing world lack access to adequate safe drinking water (WHO and UNICEF 2010). The problem is more acute in urban areas of developing countries (Vairavamoorthy et al., 2008).

As with other cities in the Hindu Kush-Himalayan (HKH) region, Kathmandu city faces acute water shortages, exacerbated by its rapid population growth driven partly by high rural-urban migration. While demand for water in Kathmandu city has increased considerably over the past few decades, supply has been dwindling because of poor management and the degradation of adjacent watersheds, particularly the Shivapuri-Nagarjun National Park (SNNP) watershed, which is the main source of water supply to Kathmandu city.

As a result, the gap between demand and supply has been increasing. The Kathmandu Valley Water Supply Limited (KUKL), the sole supplier of piped water to the city, has failed to supply enough water to meet the demand. Demand for water in the city is about 320 million litres per day, but the KUKL on average supplies only 117 million litres (KUKL, 2009). The shortfall is partly met by private water tankers, which draw water from various streams and sell it to at a premium. The shortage of water has adversely affected the lives of the 2.5 million people in Kathmandu valley (CBS, 2011).

Although interest in addressing the water problem through investment in green infrastructure such as watershed conservation is growing the world over (Pires, 
2004), views of scholars on the relationship between watershed conservation and water yield are divided. Some scholars argue that there is no relationship between watershed conservation and water yield (Bruijnzeel, 2004). Against this view, a large number of scholars (Myers, 1983; Sharp and Sharp, 1982; Spears, 1982) claim that there is a positive relationship between watershed conservation and downstream water yield. They alleged that deforestation reduces the water retention function of watersheds and increases the frequency and intensity of floods and droughts, resulting in less water. They maintain that forest cover helps to break the impact of rainfall, slowing the rate of runoff and increasing infiltration rates and aquifer recharge, thus supporting base-flow during dry periods.

Planting trees in degraded watersheds restores the water retention function of watersheds and increases downstream water yield (Daily, 1997; Emerton and Bos, 2004). Although the literature suggests a positive relationship between forest conservation and water yield, there is a dearth of empirical studies to provide compelling evidence of this. Moreover, there is little information on the possible livelihood effects of payment for ecosystem services (PES).

The specific objectives of this study were to examine the impact of upstream forest conservation on downstream water yield and the possible livelihood benefits from PES and the application of the principles of the green economy to determine the likely contribution of PES to a green economy. In doing so, this study endeavours to answer three related questions: Does upstream forest conservation increase the base flow of water? If so, is the value of the additional water flow enough to generate welfare to the upstream communities to encourage them to undertake conservation? Are the benefits sufficient to attract stakeholders to institute a PES system to address the three related issues of livelihood improvement, conservation, and water shortage? Although this study is in a watershed in Nepal, its findings are expected to be relevant to other mountain regions in the tropics and sub-tropics, where demand for water is steadily increasing.

\section{Methodology}

\section{Study Area and Data}

The study was conducted in Shivapuri-Nagarjun National Park (SNNP) in Nepal on the northern fringe of Kathmandu valley. Though the national park was established in 2002, its conservation started in 1984. The average annual rainfall is $1,900 \mathrm{~mm}$, of which nearly 80 per cent occurs during the monsoon from July to September (NTNC, 2008). The empirical analysis is conducted in the Sundarijal sub-catchment of Shivapuri-Nagarjun National Park, which has an area of 15.76 square kilometres. As part of the watershed is inhabited, water consumed by households for agriculture also depletes the water in the watershed. The stream flow and the water supply to the Kathmandu valley is the residual after all other water uses. 
Hydrometeorological data were collected from the Department of Hydrology and Meteorology of Nepal for monthly rainfall and discharge gauged in the Sundarijal sub-catchment (latitude $27.46^{\circ} \mathrm{N}$ and longitude $85.25^{\circ} \mathrm{E}$, elevation $1,490 \mathrm{~m}$ ) from 1993 to 2009. Data on cost of cultivation for the major crops were obtained from Department of Agriculture (DFAMS, 1991; MoAC, 2009).

\section{Analytical Framework}

Causal and Cost-Benefit Analysis were used as an analytical framework. An econometric analysis of hydro meteorological data was conducted to examine the relationship between forest conservation and water yield.

To answer the first research question, a water production function was estimated following Randhir and Hawes (2009). The hypothesis is that forest conservation and precipitation, after controlling for seasonal variations, affects the water discharge from the Sundarijal watershed. The monthly discharge rate $(Y)$ from the watershed was a function of precipitation in the watershed $(P)$, season $(M)$, and conservation effort $(X)$ with a lag $(t)$. The conservation effort is a dummy ( 1 for the year after the start of the conservation in 1984 and 0 before that). Mathematically, the discharge is expressed as:

$$
Y=\beta 0+\beta_{1} P+\beta_{\mathbf{2}} M+\beta_{\mathrm{z}} X_{-\mathrm{t}}+\varepsilon
$$

Where, $\varepsilon$ captures the random effects and $\beta_{1}, \beta_{2}$, and $\beta_{3}$ are the estimated coefficients. Considering the seasonal pattern of precipitation, the months of MarchApril-May (MAM) were taken as a dummy for the dry season, as these months have the lowest discharge rate.

Considering the time taken to regenerate the natural forest after commencing conservation and the availability of longitudinal meteorological data, 10 and 15year lag periods were incorporated into the model. Estimation of the model for less than 10 years and more than 15 years is not permitted by the time series data due to limited degrees of freedom. The marginal physical productivity of water from the conservation of the watershed was estimated using the biophysical valuation model. This approach assesses the value based on the intrinsic properties of objects by measuring underlying physical parameters.

The second question was answered by estimating the financial cost-benefit ratio. For this purpose, the marginal physical production of water was converted into monetary units. The benefits were estimated first by using the market price and then by using the shadow price for economic analysis. The rate of the discharge affected by the conservation was capitalised into monetary terms using the producer's surplus, i.e., the difference between the price of water and the cost of water harvesting. 
In this analysis, the time horizon was assumed to be continuous with a permanent conversion of farmland into conservation area. The producer's surplus per unit of water was used for the valuation of water services generated by the conservation of the watershed. Inputs and other production costs were deducted from the market price to find the marginal value of the water service. Per unit cost of water supply (harvesting, treating, and distributing) actually incurred by the water company was deducted from the actual per unit sale price of the water. For the purpose of comparison, the value of crop production from the farmland was estimated using the farm gate price of the agricultural products; note agricultural products are neither taxed nor subsidised in Nepal.

The third question, how to attract stakeholders to institute a PES, thereby contributing to the green economy and addressing livelihood problems of upstream communities using economic analysis of water services, was then tackled. The economic value of an additional unit of water was determined by estimating the average willingness of Kathmandu residents to pay for water, as reported by Whittington et al. (2002).

The consumers' surplus was estimated by subtracting the actual price residents were paying from the Figures, indicating their willingness to pay. With the consumers' surplus as the flow of the benefit of land conversion and the opportunity cost as the net return from cultivating the land, the net present value (NPV) and internal rate of return (IRR) of land conversion were estimated. Using the social nature of the analysis a discount rate of 8 per cent per annum was used.

\section{Results \& Discussion}

\section{Effects of Conservation on Water Discharge}

The mean monthly rainfall in, and average discharge from, the Sundarijal subcatchment are $191 \mathrm{~mm}$ and 1.21 cubic metres per second, respectively. Descriptive statistics of the variables used in the production function are presented in Table 1. The estimated effects of conservation on stream flow, with 10 years lag, are presented in Table 2.

It is evident from the results that each millimetre increase in monthly rainfall increases the discharge by 3 litres per second, which is equal to 49 per cent of the total influx. As expected, the discharge was significantly lower during the MAM dry season as compared to other months. Even 10 years after the start of conservation, the water discharge from the watershed had not increased significantly. As expected, longer lag periods increased the water flow. The results of a 15-year lag period show that every millimetre increase in rainfall increases the water discharge by 4 litres per second (Table 3 ). 
Table 1: Descriptive statistics of monthly rainfall and discharge

\begin{tabular}{|c|c|c|c|c|c|c|}
\hline Variable & Unit & Months & Mean & Std. Dev. & Mini & Maxi \\
\hline Rainfall & mm per month & 185 & 190.93 & 251.36 & 0.00 & 1176.00 \\
\hline Discharge & Average discharge $\left(\mathrm{m}^{3} \mathrm{~s}^{-1}\right)$ & 185 & 1.21 & 1.20 & 0.12 & 5.62 \\
\hline Base flow & $\begin{array}{l}\text { Average discharge in } \\
\text { MAM }\left(\mathrm{m}^{3} \mathrm{~s}^{-1}\right)\end{array}$ & 45 & 0.39 & 0.28 & 0.12 & 1.2 \\
\hline
\end{tabular}

Note: MAM=the months of March-April-May

Source: Calculated from the data of Department of Hydrology and Meteorology, Kathmandu.

Table 2: Effects of rainfall and 10 years of forest conservation on water discharge

\begin{tabular}{lllccrr}
\hline \multicolumn{1}{c}{ Variables } & \multicolumn{1}{c}{ Coefficient } & $\begin{array}{c}\text { Std. } \\
\text { Err. }\end{array}$ & \multicolumn{1}{c}{$\boldsymbol{t}$} & $\boldsymbol{P}>|\boldsymbol{t}|$ & \multicolumn{2}{c}{$\begin{array}{c}\text { 95\% Confidence } \\
\text { Interval }\end{array}$} \\
\hline Rainfall & $0.003 * * *$ & 0.000 & 15.700 & 0.000 & 0.003 & 0.004 \\
Dry season (MAM) & $-0.668 * * *$ & 0.128 & -5.240 & 0.000 & -0.920 & -0.416 \\
Conservation lag10 & 0.139 & 0.187 & 0.750 & 0.457 & -0.229 & 0.507 \\
Constant & $0.590 * * *$ & 0.190 & 3.110 & 0.002 & 0.216 & 0.965 \\
\hline
\end{tabular}

Notes: Conservation lag $10=$ conservation with 10 years lag period.

*** for $1 \%$ level of significance, ** for $5 \%$ level of significance and * for $10 \%$ level of significance.

Table 3: Effects of rainfall and 15 years of forest conservation on water discharge

\begin{tabular}{llllllll}
\hline & Variables & Coefficient & $\begin{array}{l}\text { Std. } \\
\text { Err. }\end{array}$ & $\boldsymbol{T}$ & $\boldsymbol{P}>|\boldsymbol{t}|$ & $\begin{array}{l}\text { 95\% } \\
\text { Interval }\end{array}$ \\
\hline 1 & Rainfall & $0.004^{* * *}$ & 0.000 & 16.020 & 0.000 & 0.003 & 0.004 \\
2 & Dry season (MAM) & $-0.661^{* * *}$ & 0.126 & -5.240 & 0.000 & -0.910 & -0.412 \\
3 & Conservation lag15 & $0.233^{* *}$ & 0.109 & 2.140 & 0.034 & 0.018 & 0.448 \\
4 & Constant & $0.567 * * *$ & 0.105 & 5.390 & 0.000 & 0.360 & 0.774 \\
\hline
\end{tabular}

This is similar to, but stronger than, the results of the 10-year lag model. However, conservation significantly increased water discharge. On average, conservation with a 15-year lag increased water discharge to 233 litres per second. This increase is an average of 19.25 per cent of the original discharge, which seems reasonable when compared to other studies (e.g., Lara et al., 2009) report a mean increase of 14.1 per cent in total summer stream flow in Chile for every 10 per cent increase in native forest cover in the watershed). 


\section{Water Benefits of the Proposed Conservation Area}

The increase in water flow after a time lag of 15 years leads to an additional water supply of $596,160 \mathrm{~m}^{3}$ per month. The cost of water collection, treatment, and distribution, as incurred by the water company, is Nepali Rupees (NPR) 3.17 per cubic metre (KUKL, 2009) (1 US\$=NPR 75).

The same operational cost is used for the additional water, assuming that any rise in the marginal cost of water handling gets compensated for by economies of scale in handling. Although the retail price of potable water as fixed by Kathmandu Valley Water Supply Management Board, the regulating body for water supply in Kathmandu, is NPR 39 per cubic metre, the realised average return of the water company (after leakage, defaulters, and other inefficiencies) obtained from the records of the company is NPR 10.21 per cubic metre.

Assuming that the efficiency of water supply is unchanged, and using the realised return and incurred costs of the water, the producer's surplus per unit of water comes to NPR 7.04 per cubic metre. Thus, the net revenue from additional water production from conservation is calculated at NPR 50.36 million per annum. This value was generated from the conservation of 1,376 hectares of forest (out of a total of 1,576 hectares). The remaining 200 hectares within the catchment is still under traditional farming (NTNC, 2008).

Hence, if existing farmland is converted into conservation area, it can produce 5,200 cubic metres of additional water per hectare generating a value of NPR 36,600 per hectare. As the water company is running below capacity, it can safely be assumed that the additional water production from the conversion of the farmland into conservation area does not need additional investment in infrastructure. This estimate is higher than estimates reported for other rural areas, such as those by Khanal et al., 2010) who, using an open bid contingent valuation method, estimated the value of water services from community forests to be NPR 7,397 per hectare in a rural area of western Nepal.

\section{Opportunity Cost of Land Conversion and Financial Cost-Benefit Analysis}

Upstream farmers will be able to allocate their land for conservation only if their opportunity cost in doing so is covered. The major portion of the opportunity cost of allocating land for conservation is returns from the cultivation of traditional crops. The existing cropping patterns are maize-millet-fallow and maize-rice-fallow, meaning two crops per year are grown: maize (Zea mays) during spring (April to June) followed by rice (Oryza sativa) in irrigated areas or finger millet (Eleusine coracana) in non-irrigated areas during the wet season (July to November).

Located on sloping land with a fragile farm environment, crop yields are very low. The yields of the major crops, finger millet, rice, and maize, are 1.09, 2.02, and 2.95 tonnes per hectare, respectively (DFAMS, 1991; MoAC, 2009). The net income 
from millet, which includes the revenue from the main product and straw as a byproduct after deducting the cost of production, is NPR 4,450 per hectare. Similarly, the net income from rice is NPR 12,027 per hectare and from maize is NPR 12,284 per hectare. Considering the cropping pattern the annual average net return from crop cultivation comes to NPR 18,249 per hectare. The financial benefit-cost ratio of converting the farmland into conservation area is 2.01 .

These estimates use the producer's surplus obtained from the market price of water, which is administratively determined by the government and is a less reliable indicator of the value of water to the consumers of Kathmandu valley. However, the price thus established is relevant to the water supply company in developing a PES mechanism.

\section{Development of a PES Mechanism for a Green Economy and Livelihood Improvement}

The analysis in the previous section demonstrates that the financial value of the increased water flow received by the water supply company is larger than the opportunity cost of land conversion. The surplus is enough to encourage stakeholders to adopt green infrastructural development through the institution of a PES mechanism. However, the water supply company may be reluctant to make payments for such services during the gestation period.

Another problem for the water company in setting up a PES system is that the company operates the water supply scheme on a 30-year lease from the Kathmandu Valley Water Supply Management Board (KVWSMB). The development of a PES mechanism for land conversion requires the involvement of the KVWSMB and the water supply company. The KVWSMB needs to work as an intermediary, charging the amount to the water company and paying the upstream farmers. In future leases of the water supply infrastructure, PES can be incorporated in the terms of the lease agreement so that the green economy is adopted by upstream communities. However, an economic analysis is necessary before recommending external assistance and policy changes.

\section{Economic Cost-Benefit Analysis of Land Conversion}

The economic value of water can be measured by its use-value to consumers. Studies show that households in Kathmandu valley are willing to pay a significantly higher amount for improved water services than they are currently paying (Pattanayak et al. 2005). Whittington et al. (2002) report that the mean monthly willingness to pay (WTP) of Kathmandu residents for 15 cubic metres of improved water supply is NPR 1,030, which is equivalent to NPR 68.67 per cubic metre.

Consumers are receiving piped water for a much lower price (NPR 39 per cubic metre). However, the supply is limited. Using WTP and the price actually being paid, the consumers' surplus comes to NPR 29.67 per cubic metre of water. Thus, 
the consumers' surplus generated by 5,200 cubic metres of water per hectare of land converted from farm to conservation forest is NPR 154,284 per hectare, which is the economic value generated by the conservation. It can be concluded that each hectare of farmland converted to conservation area generates water equivalent to this amount every year after a 15-year lag time.

Comparing the economic benefits of the water with the opportunity cost of the land conversion, the economic benefit-cost ratio comes to 8.45 , which is attractive for investment in land conversion. The payback period for land conversion is 19 years. The net present value (NPV) for the indefinite future is NPR 410,218 per hectare of land. Using the value of water services, the opportunity cost of land, and the time lag required to realise the benefits of land conversion, the internal rate of return (IRR) is estimated to be 15.29 per cent, an attractive rate of return on investment.

This benefit, however, does not include the benefits from the potential future harvest of forest products, biodiversity conservation, carbon sequestration, and other ecosystem services. Considering the social benefits of land conversion from a long-term perspective, external funding is well justified for the purpose, particularly during the initial years.

\section{Conclusions}

This study examined the role of PES in improving the livelihoods of upstream communities and the conservation of watershed. The results suggest that, if properly implemented, PES can provide the twin benefits of improving livelihoods and conserving the watershed. The results indicate that conservation increases water flow, and the value generated from additional water flow is enough to improve the livelihoods of the upstream communities. The land use determines the vegetation and the vegetation reduces water movement, intercepts the water, and returns a portion of it to the atmosphere through evapotranspiration (Hamilton, 1987).

For the hills in Nepal, where rainfall is seasonal, the slow movement of runoff in forestland leads more infiltration of water during the rainy season than in agricultural land. This increases the base flow during the dry season, which is evident from the fact that rainfall has decreased in recent years whereas discharge has increased, particularly during the post monsoon season (Figure 1).

The economic analysis shows that the value generated from additional water flow is more than enough to compensate upstream farmers for setting aside their land for conservation. The additional benefits can be distributed among the upstream and downstream communities to improve their livelihood. It is recommended that farmers are paid under equivalent variation, so that they can benefit from the conservation efforts through improved livelihood. It is expected that PES will encourage farmers to conserve the ecosystem helping the society to protect green infrastructure for water supply and move towards a green economy. 


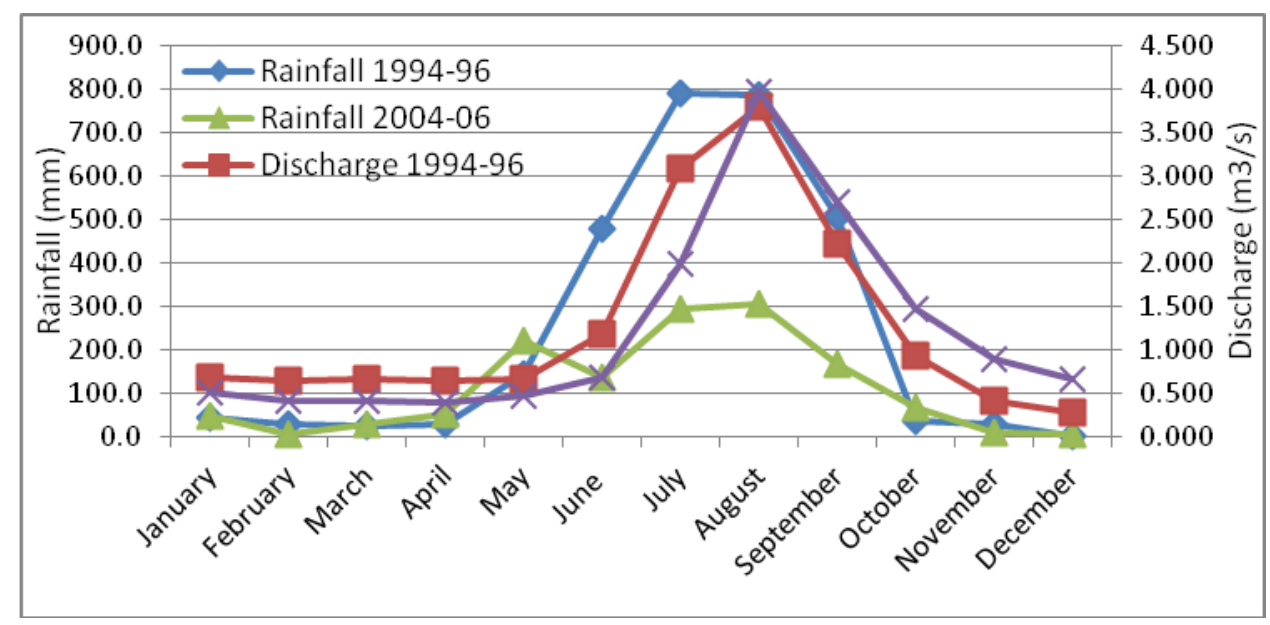

Data source: Department of Hydrology and Meteorology, Kathmandu

\section{Figure 1: Shifts in monthly patterns of precipitation and discharge}

The findings of this study have important policy implications; they show that upland forest conservation can increase water services to downstream populations, while also improving the livelihoods of upstream communities and contributing to a green economy. Converting 200 ha of low productivity farmland adjacent to the capital city does not have significant implications for food security.

Transporting food from outside the city is much cheaper than transporting water. Though the food self-sufficiency will be lower among the upstream communities, they can buy food from the market with the money received from the PES. Considering the location advantages of the farmland in the Sundarijal subcatchment, water conservation will make the society better-off than producing food grain.

Accordingly, two sets of policies are proposed for farmland conversion to conservation area. First, a set of policies is needed to facilitate the conversion of farmland owned by upstream communities into conservation area. The second set of policies consists of those necessary for instituting a PES mechanism.

Payment to farmers for the ecosystem services of their farmlands will improve the livelihoods of upstream communities, conserve the ecosystem, and address the issue of water shortage in Kathmandu. PES is a market tool and can encourage investment in the conservation of ecosystems and promote a green market and green economy. PES can be a promising mechanism for stakeholder participation in a green economy and mainstream green growth policies for the pursuit of sustainable development and the improvement of the livelihoods of mountain communities. 
This approach of economically valuing hydrological services has practical relevance in facilitating PES, particularly in peri-urban watersheds, in other mountainous countries in the tropics and sub-tropics. However, transferring benefits to mountain regions needs to be done carefully and may need customisation to the local context, as the value of water is context-specific and the precipitation-stream flow relation location specific. However, the approach and methodology applied in this paper might be useful in other mountainous regions and can contribute to the design of a PES scheme for hydrological services and the promotion of the green economy.

\section{References}

Bruijnzeel, L. A. (2004). "Hydrological functions of tropical forests: Not seeing the soil for the trees?" Agriculture, Ecosystems and Environment, 104: 185-228.

CBS (2011). "Population census 2011, preliminary results". Kathmandu: Central Bureau of Statistics, Government of Nepal.

DFAMS (1991). "Report on cost of production for major crops in Nepal (1989/90)." Kathmandu: Ministry of Agriculture, Department of Food and Agriculture marketing Services, Economic Analysis Division, Government of Nepal.

Emerton, L., E. Bos (2004). "Value, counting ecosystems as an economic part of water infrastructure." Switzerland and Cambridge, UK: IUCN and Gland.

Hamilton, L. (1987). "What are the impacts of Himalayan deforestation on the GangesBrahmaputra lowlands and delta: Assumptions and facts." Mountain Research and Development 7(3): 256-263.

Hunzai, K., J. Y. Gerlitz, B. Hoermann, M. Kollmair, (2010). "Understanding Mountain Poverty." ICIMOD Information Sheet 3/10. Kathmandu, Nepal: ICIMOD.

Khanal, Y., C. P. Upadhyaya, R. P. Sharma (2010). "Economic valuation of water supply service from two community forests in Palpa district." Banko Janakari, 20 (1): 24-29.

KUKL (2009). "Second annual report. Kathmandu Valley Water Supply Limited", pp. 1124. www.kathmanduwater.org and www.kvwsmb.org.np (accessed 12 November 2010).

Lara, A., C. Little, R. Urrutia, J. McPhee, C. A. lvarez-Garreton, C. Oyarzun, D. Soto, P. Donoso, L. Nahuelhual, M. Pino, I. Arismendi, (2009). "Assessment of ecosystem services as an opportunity for the conservation and management of native forests in Chile." Forest Ecology and Management, 258: 415-424.

MoAC (2009). "Statistical information on Nepalese Agriculture." Kathmandu: Ministry of Agriculture and Cooperatives, Government of Nepal.

Myers, N. (1983). "Tropical moist forests: Over-exploited or under-utilized?" Forest Ecological Management, 6: 59-79.

NTNC (2008). "Bagmati action plan". National Trust for Nature Conservation, Kathmandu. 
Pattanayak, S. K., J. C. Yang, D. Whittington and B. K. KC (2005). "Coping with unreliable public water supplies: Averting expenditures by households in Kathmandu, Nepal." Water Resources Research, 41(2):1-11.

Pires, M. (2004). "Watershed protection for a world city: The case of New York." Land Use Policy, 21: 161-175.

Randhir, T. O., A. G. Hawes, (2009). "Watershed land use and aquatic ecosystem response: Ecohydrologic approach to conservation policy." Journal of Hydrology, 364: 182-199.

Sharp, D., and T. Sharp (1982). "The desertification of Asia." Asia 2000, 1: 40-42.

Spears, J. (1982). "Rehabilitating watersheds." Finance Development, 19: 30-33.

UNEP (2010). "Green Economy Developing Countries Success Stories." www.unep.org/greeneconomy (accessed 05 January 2011).

Vairavamoorthy, K., S. D. Gorantiwar and A. Pathirana (2008). "Managing urban water supplies in developing countries - Climate change and water scarcity scenarios, Physics and Chemistry of the Earth, Parts A/B/C," Integrated Water Resources Management in a Changing World, 33(5): 330-339.

Whittington, D., S. K. Pattanayak, J. C. Yang and B. K. KC (2002). "Do households want privatized municipal water services? Evidence from Kathmandu, Nepal," Working Paper 02_03 March 2002. Research Triangle Park, NC: Research Triangle Institute. 